\title{
Research Design for Testing Archaeological Site 41RB31 Roberts County FM 3367
}

Joe T. Denton

Follow this and additional works at: https://scholarworks.sfasu.edu/ita

Part of the American Material Culture Commons, Archaeological Anthropology Commons, Environmental Studies Commons, Other American Studies Commons, Other Arts and Humanities Commons, Other History of Art, Architecture, and Archaeology Commons, and the United States History Commons

Tell us how this article helped you.

This Article is brought to you for free and open access by the Center for Regional Heritage Research at SFA ScholarWorks. It has been accepted for inclusion in Index of Texas Archaeology: Open Access Gray Literature from the Lone Star State by an authorized editor of SFA ScholarWorks. For more information, please contact cdsscholarworks@sfasu.edu. 


\section{Research Design for Testing Archaeological Site 41RB31 Roberts County FM}

3367

\section{Licensing Statement}

This is a work produced for the Texas Department of Transportation (TxDOT) by the report producer. TxDOT and the report producer jointly own all rights, title, and interest in and to all intellectual property developed under TXDOT's contract with the report producer. The report may be cited and brief passages from this publication may be reproduced without permission provided that credit is given to both TXDOT and the report producer. Permission to reprint an entire chapter, section, figures or tables must be obtained in advance from either the Supervisor of the Archeological Studies Branch, Environmental Affairs Division, Texas Department of Transportation, 125 East 11th Street, Austin, Texas, 78701 or from the report producer. 
RESEARCH DESIGN FOR TESTING

ARCHAEOLOGICAL SITE 41RB31

ROBERTS COUNTY

PM 3367

Joe T. Denton

Texas

State Department of Highways and Public Transportation Highway Design Division

June 1984 
INTRODUCTION

Archaeological Site 41 RB31 is located at the edge of the cap rock overlooking Red Deer Creek, approximately 1.2 miles south of US 60 at the junction of proposed FM 3367 and a second county road. At the present time, the site appears to be a relatively undisturbed single component site.

Testing of portions of the site within the proposed highway right-of-way is being initiated by the State Department of Highways and Public Transportation (SDHPT) in accordance with Procedures for the Protection of Historic and Cultural Properties (36 CFR, Part 800), procedures which are prescribed by law and endorsed by the Federal Highway Admini stration. Objectives of the test are to determine the nature of the site, its cultural affiliation and whether those portions included within the highway right-of-way meet the criteria for inclusion within the National Register of Historic Places.

Testing will deal specifically with the determination of the depth of the deposits which contain archaeological materials and the determination of a more precise site limit within the SDHPT right-of-way. Of prime concern will be the cultural context and stratification of material present. Artifacts and associated cultural debris will be recorded in situ, where possible. Cultural features, if encountered, will be investigated to the 
extent of determining the nature and possible affiliation and/or significance of those features. Documentation will consist of field notes, level reports, drawings, and photographic records. 


\section{PROJECT DESCRIPTION}

The project consists of improvements to an existing unpaved county road to provide for a farm to market roadway of two $12 \mathrm{ft}$. paved travel lanes and shoulders. Existing roadway width is 40 to $60 \mathrm{ft}$. to be widened to $100 \mathrm{ft}$. with some new alignment. The project length is approximately 5.0 miles. 


\section{SITE DESCRIPTION}

Archaeological Site 41RB31 is located on the edge of the escarpment of the cap rock overlooking Red Deer Creek. The site is west of the existing county road and appears to be entirely within the limits of the proposed new right-of-way. Soils in the area are a clay loam and are presently subject to wind and water erosion. Ground cover consists of short grasses and some cacti and shrubs. Surface visibility is generally good. The soil bearing the archaeological material appears shallow, less than 30 cm thick based on soil profiles provided by erosional rills. Total area of the site appears to be less than 1 acre. The site was evidenced by flakes and a single projectile point fragment. The site appears to be an open campsite and chipping station. 


\section{TESTING PROCEDURES}

Archaeological testing will consist of no fewer than 4 nor more than 10 hand-excavated units. These units will be 1 by 2 meters and will be excavated in $10 \mathrm{~cm}$ levels from ground surface to sterile deposits.

Horizontal control will be maintained by utilizing the SDHPT project centerline, a known line of exact legal declination. Vertical control will be maintained in relation to the present ground surface of each test unit. Soil matrix excavated from the test units will be passed through 0.25 in. hardware cloth, and all recovered artifacts and cultural debris will be retained for analysis. Similarly, all faunal material will also be retained. Recovered materials will be bagged, labeled according to provenience, and removed from the site to the SDHPT Archaeology Laboratory for temporary curation.

Horizontal placement of units will be based on surface observations and trends noted during testing. In addition, some units will be placed along the perimeter of the site in order to determine the exact site boundary within the right-of-way.

Documentation will consist of daily field notes, level reports, drawings and photographic record. 
Upon completion of the testing, a report detailing the results will be prepared with approporiate maps, profiles, photographs, and scale drawings. Additional recommendations will be made at that time, as well as determination of eligibility for inclusion within the National Register of Historic Places. 
RESOURCE POTENTIAL

Archaeological Site 41RB31 occurs within an area of great archaeological wealth. Yet the area lacks archaeological documentation for much of the prehistoric period. Primary emphasis has been given to the Paleo-Indian Period almost to the exclusion of the Archaic Period. The Late Prehistoric Period has been somewhat better documented, particularly the Antelope Creek Focus.

The Resource Protection Planning Process (RP3) as prepared by the Texas Historical Commission (Brown et al . 1982) outlines the principal Texas archaeological study units and establishes some needs within each study unit. Site 41RB31 occurs within the High Plains Archaic study unit (7000 B.P. to A.D. 500) and the Canadian Basin Late Prehistoric study unit (A.D. 500 to A.D. 1528). Specific problems in the region include an indeterminate cultural sequence for the Archaic Period. The Late Prehistoric Canadian Basin study unit centers around the largely agricultural, semisedentary culture of the Antelope Focus.

Site 41RB31 does not appear to have great depth but appears to have intact deposits which could yield some information regarding cultural sequence. Areas of specific use might also be defined. 
On the basis of the general lack of excavated archaeological record for the Archaic and Late Prehistoric Periods and the potential for some cultural stratification, it is believed that testing of the site should be initiated. 


\section{REFERENCES CITED}

Brown, Theodore M., Kay L. Killen, Helen Simons, and Virginia Wolfkuhle 1982 Resource Protection Planning Process for Texas. Texas Historical Commission. Austin.

PAGE 10 